\title{
Corrosion of 3D-Printed AISi9Cu3Fe Alloy
}

\author{
Michaela Fousova ${ }^{1,2}$, Veronika Valesova ${ }^{1}$, Dalibor Vojtech ${ }^{1}$ \\ ${ }^{1}$ Department of Metals and Corrosion Engineering, Faculty of Chemical Technology, University of Chemistry and Tech- \\ nology Prague, Technicka 5, 16628 Prague 6, Czech Republic. E-mail: fousovam@vscht.cz, valesovv@vscht.cz, voj- \\ techd@vscht.cz \\ ${ }^{2}$ Institute of Physics, Academy of Sciences of the Czech Republic (AS CR), Na Slovance 1999/2, 18221 Prague 8, Czech \\ Republic.
}

\begin{abstract}
Although 3D printing offers many advantages over casting, it can alter the corrosion behaviour of processed metals and alloys. The corrosion behaviour is related primarily to the microstructure, which is very fine and heterogeneous in 3D printed metals due to very high cooling rates and the additive way of manufacture layer by layer. Therefore, we carried out corrosion tests according to the Audi internal standard to demonstrate how the 3D printing process influenced the corrosion behaviour of the AISi9Cu3Fe alloy prepared by selective laser melting compared to a conventional casting. Corrosion rates were determined from mass losses and corrosion attacks were documented microscopically. Compared to the cast material, the corrosion rate was increased by $\sim 60 \%$ after $3 \mathrm{D}$ printing. Related to the microstructural heterogeneity and anisotropy, an uneven attack was observed on different sides of the tested samples.
\end{abstract}

Keywords: AlSi9Cu3Fe, corrosion, 3D printing

\section{Introduction}

AlSi9Cu3(Fe) alloy belongs among the most used aluminium alloys, especially in automotive industry (cylinder heads, blocks etc.), thanks to its high strength-toweight ratio, superior machinability and castability. Mostly, complicated castings or thin-walled products are manufactured by using pressure casting. High-pressure die-casting (HPDC) is predominantly used for the massive production of automotive components because it is characterized by good flexibility, high production speed and capability to create complex geometries with good surface quality. The main drawback of the HPDC is the formation of casting defects, such as gas porosity, oxide films and cold joints [1,2].

$\mathrm{AlSi} 9 \mathrm{Cu} 3(\mathrm{Fe})$ alloy is an hypoeutectic alloy so that its as-cast microstructure formed under normal cooling conditions consists of dendrites of $\alpha(\mathrm{Al})$ solid solution and needle-like eutectic silicon. Copper forms $\mathrm{CuAl}_{2}$ hard phase at grain boundaries. If iron is present in the alloy, harmful $\beta-\mathrm{Al}_{5} \mathrm{FeSi}$ phase is also present $[3,4]$. Needle-like $\mathrm{Si}, \mathrm{CuAl}_{2}$ phase and $\beta$-phase all negatively affect the alloy's strength and ductility [5]. Therefore, there are different ways how to effectively improve the mechanical properties of castings.

The needle-lie morphology of eutectic silicon can be altered by three main approaches. First, by technological approach; e.g. squeeze casting enhances the amount of solid solution and refine and homogenize the eutectic silicon, similarly to complex modification treatments $[5,6]$. With cooling rates up to $10^{2} \mathrm{C} / \mathrm{s}$, HPDC also brings refinement [7]. Second, modification by addition of various elements is possible. The addition of small amounts of $\mathrm{Sr}$ to the melt alters the acicular morphology of Si to a fibrous one, which brings about a great improvement in the mechanical properties. Silicon particle characteristics can also be affected through thermal modification by subjecting the casting to a high temperature treatment for extended periods [8].
To inhibit the monoclinic crystallization of $\beta-\mathrm{Al}_{5} \mathrm{FeSi}$ particles during solidification, alloying elements such as $\mathrm{Mn}, \mathrm{Ni}, \mathrm{Co}, \mathrm{Sr}, \mathrm{Mo}, \mathrm{Ca}, \mathrm{K}$ and $\mathrm{Be}$ can be added. It is a common practice to add a small quantity of manganese $(\mathrm{Fe}: \mathrm{Mn}=2: 1)$ to convert the crystallization of iron intermetallics in a platelike form ( $\beta$-phase) to a Chinese script form ( $\alpha$-phase) $[9,10]$. Also, a fragmentation of harmful Fe-phases by suitable heat treatment is possible [11].

The 3\% copper content gives the alloy possibility of precipitation strengthening by $\mathrm{CuAl}_{2}$ precipitates induced by proper heat treatment. During solution treatment, the hard $\mathrm{CuAl}_{2}$ phase present at grain boundaries dissolves and a supersaturated solid solution is formed after quenching. Following aging brings formation of $\mathrm{CuAl}_{2}$ precipitates, effectively blocking dislocation motion. However, while these precipitates give the alloy high strength, they also reduces its corrosion resistance; microgalvanic cells are formed between $\mathrm{CuAl}_{2}$ and $\mathrm{Al}$ matrix $[12,13]$.

3D printing, a popular term for additive manufacture (AM), provides solution to all the above-mentioned issues. AM of metals can be classified among methods of rapid cooling. With rapid cooling, higher fraction of alloying elements remains trapped in the solid solution so that oversaturated solid solutions are formed and less secondary phases are present in the microstructure. Rapid cooling also brings microstructure refinement [14].

The most wide-spread methods of AM of metals are based on localized melting of metallic powder and its gradual consolidation. In selective laser melting (SLM), a laser beam is used to melt the material. For electron beam melting (EBM), a beam of electrons is applied. Because only a very small amount of powder is melted at one point and the melt is surrounded by loose powder and/or chilled solidified material, the heat dissipation is very fast [15]. Cooling rates can reach up to $10^{8}{ }^{\circ} \mathrm{C} / \mathrm{s}$ [16]. As a result, very fine microstructures with strengths going even beyond those of traditionally prepared metals are 
formed by AM. Moreover, the main advantage of AM is an enormous geometrical freedom of fabricated products. In combination with light aluminium alloys, AM can provide great weight reduction of automobile parts and so saving environment from pollution and $\mathrm{CO}_{2}$ emissions [17].

Nevertheless, except from lightness and strength, corrosion resistance is also important for automobile parts. Therefore, in this paper, we report on the corrosion behaviour of the AlSi9Cu3Fe alloy prepared by SLM. To provide the first idea about the corrosion resistance, we carried out immersion tests set by an internal standard of Audi company. In comparison to a conventionally prepared casting, despite the microstructure fineness and absence of intermetallic phases, SLM yielded an intensification of the corrosion attack.

\section{Experimental Setup}

\subsection{Specimens preparation}

The subject of this work is $3 \mathrm{D}$ printing, specifically the selective laser melting (SLM) technology. The samples of AlSi9Cu3Fe alloy used in this study were printed on an SLM Solution 280HL machine by NETME Centre in Brno. A chess board scanning strategy was applied, with a hatching distance between adjacent scan lines of $150 \mu \mathrm{m}$. Input powder of AlSi9Cu3Fe alloy (LPW) with particle size of $40 \mu \mathrm{m}$ was deposited onto the building plate in $50 \mu \mathrm{m}$ thin layers. The laser melting process, using a laser of $400 \mathrm{~W}$ in power, was carried out under protective argon atmosphere.

As reference material, casting prepared commercially by high-pressure die casting (HPDC) were used. Chemical composition of both alloys is given in Table 1 .

Tab. 1 Chemical composition of the studied alloy.

\begin{tabular}{|c|c|c|c|c|c|c|c|c|c|}
\hline wt.\% & Al & Si & $\mathbf{C u}$ & $\mathbf{F e}$ & $\mathbf{M g}$ & $\mathbf{Z n}$ & $\mathbf{M n}$ & $\mathbf{T i}$ & Sn \\
\hline SLM & bal. & 8.9 & 3.1 & 1.2 & 0.3 & 0.01 & $/$ & $/$ & $/$ \\
\hline HPDC & bal. & 8.6 & 2.6 & 0.7 & 0.2 & 0.9 & 0.3 & 0.04 & 0.07 \\
\hline $\begin{array}{c}\text { CSN EN ISO } \\
\mathbf{4 2} 4339\end{array}$ & bal. & $8.0-11.0$ & $2.0-3.5$ & max. 1.0 & $0.1-0.5$ & $\max 1.2$ & $0.1-0.5$ & max. 0.15 & max. 0.1 \\
\hline
\end{tabular}

\subsection{Microstructure characterization}

For microstructural characterization, metallographic sections were prepared by cutting the samples parallel to the building direction (perpendicular to the deposited layers). The metallographic sections were ground, polished and etched in $5 \% \mathrm{HF}$, and observed by light metallographic microscope OLYMPUS PME 3 and scanning electron miscroscope (SEM) TESCAN VEGA-3 LMU equipped with EDX analyzer Oxford instruments INCA 350. Point EDX analyses were accomplished to determine the chemical composition of constituting components. Phase composition was determined by X-ray diffraction (PANalytical X'Pert PRO with $\mathrm{Cu}$ anode, High Score Plus software).

\subsection{Corrosion tests}

Corrosion tests were performed by immersion tests according to the internal Audi standard PV 11 13. Cylindrical samples of $\sim 8 \mathrm{~mm}$ in diameter and $\sim 11 \mathrm{~mm}$ in height were prepared. To ensure a defined surface, the samples were ground SiC-papers of P1200 roughness. Prior to corrosion tests, the samples were rinsed in water, degreased sonically in acetone and ethanol, and dried in hot air. Each sample was then immersed into the Audi solution $\left(1000 \mathrm{ml} \mathrm{H}_{2} \mathrm{O}, 20 \mathrm{~g} \mathrm{NaCl}, 100 \mathrm{ml} \mathrm{25 \%} \mathrm{HCl}\right)$ in a separate beaker. A ratio of $30 \mathrm{ml}$ of the solution per $1 \mathrm{~cm}^{2}$ surface area was applied. After 2 hours, samples were removed, rinsed in water and dried in hot air.

For each material, 4 samples were subjected to corrosion test. One sample was cut lengthwise, moulded into an epoxy resin and processed by a standard metallographic way. Corrosion attack was observed microscopically and the maximum depth of corrosion attack penetra- tion was assessed by image analysis (ImageJ). Other samples were pickled in a concentrated $65 \% \mathrm{HNO}_{3}$ to remove corrosion products and determine weight losses for the calculation of corrosion rate.

\section{Results and Discussion}

\subsection{Microstructure}

During SLM, a laser beam melts a powder material and transiently forms melt pools. The depth and the thickness of a melt pool depends on process parameters (such as laser power and scanning speed), scanning pattern and powder properties (absorptivity) which dictates the amount of energy given to a unit volume of a powder (energy density) and vary heat inflow and its dissipation [18]. As the laser moves away, melt pools solidify. Melt pools can be observed in the micrograph in Fig. 1a as domains bordered by bright arcs. In higher magnification (Fig. 1b), the arcs differ with a coarser substructure. The formation of the coarser substructure is given by the Gauss distribution of laser energy. At melt pool borders, melt undercooling is lower compared to melt pool centres, which results in larger cell size [19].

So-called cellular-dendritic substructure is formed in the SLM AlSi9Cu3Fe alloy due to very high cooling rates reaching up to $10^{6}{ }^{\circ} \mathrm{C} / \mathrm{s}$ [20]. The cells are formed by an oversaturated solid solution of $\alpha(\mathrm{Al})$ and the remaining silicon forms an interconnected intercellular network. Cell size ranges between 1 and $4 \mu \mathrm{m}$. EDS analysis showed that the cells of oversaturated solid solution of $\alpha(\mathrm{Al})$ contain $5.4 \pm 0.5 \mathrm{wt} . \%$ of $\mathrm{Si}, 3.2 \pm 0.4 \mathrm{wt} . \%$ of $\mathrm{Cu}$ and $1.1 \pm 0.2$ wt. $\%$ of Fe. However, with such a fine microstructure, EDS analysis is already at the edge of its resolution so that quantitative results might be biased by sili- 
con in the intercellular network. In the intercellular network, EDS maps (Fig. 2) show clear enrichment in Si, and also local occurrence of $\mathrm{Cu}$. It probably concerns some particles of $\mathrm{CuAl}_{2}$ phase, of which 2 vol.\% were detected by X-ray diffraction.

Within the melt pools, elongated grains can be distinguished (see Fig. 1a). New grains are usually nucleated at melt pool borders and grow towards its centre in the direction of the highest temperature gradient between already solidified chilled material and hot melt. Some grains grow epitaxially from grains in previous layers so that they are spread across melt pool borders. The length of elongated grains $(60-200 \mu \mathrm{m})$ approximately corresponds to the depth of meltpools $(50-250 \mu \mathrm{m})$.
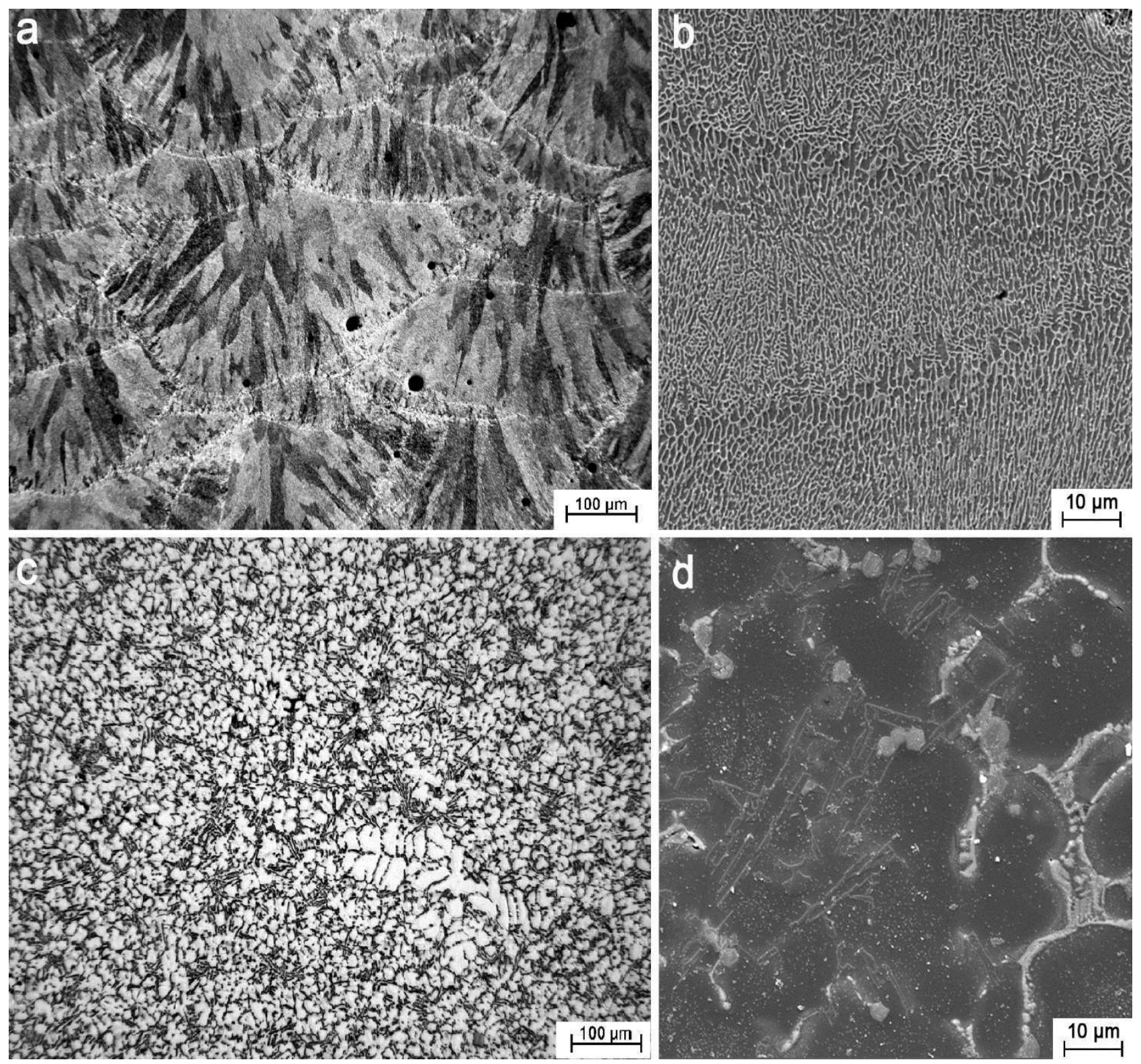

Fig. 1 Microstructure of AlSi9Cu3Fe alloy: a, b) 3D-printed; c, d) HPDC.

Apparently, the microstructure of the same alloy prepared by HPDC is completely different (Fig. 1c-d) because the material is melt at once and solidified, and also because the cooling rate of HPDC does not reach such high values as during SLM. The microstructure, in this case, consisted mainly of primary dendrites of $\alpha(\mathrm{Al})$ solid solution and eutectics containing Si needles (Fig. 1c). When the fine cellular substructure of the 3D-printed microstructure is considered, the as-cast microstructure is considerably coarser. The size of dendritic branches varied between 15 and $20 \mu \mathrm{m}$. EDS analysis revealed that the solid solution contains $1.9 \pm 0.2$ wt. $\%$ of $\mathrm{Si}$ and $0.9 \pm 0.2$ wt. $\%$ of $\mathrm{Cu}$. Due to elevated cooling rates (up to $10^{2}{ }^{\circ} \mathrm{C}$ [7]) the solid solution also shows oversaturation but not as strong as in SLM samples. Some intermetallic phases were present too (Fig. 1d). Angular particles (pentagons or hexagons) with increased amount of Fe and Mn (apparent from EDS maps in Fig. 3) were assigned to $\mathrm{Al}_{15}(\mathrm{FeMn})_{3} \mathrm{Si}_{2}$ phase. The other type of intermetallics was $\mathrm{CuAl}_{2}$ phase forming chinese-script-like formations. 

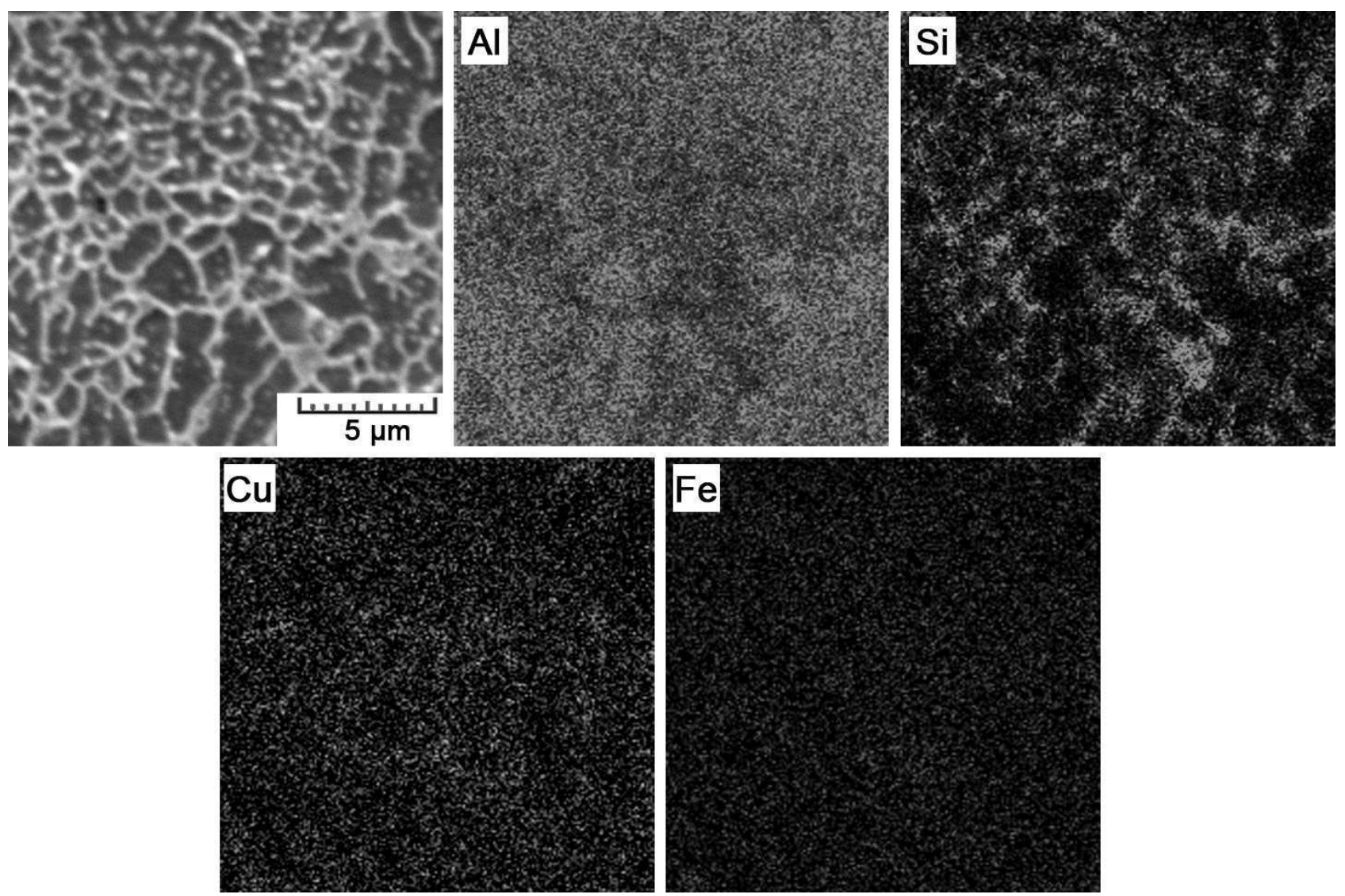

Fig. 2 EDS maps of 3D-printed AlSi9Cu3Fe alloy.
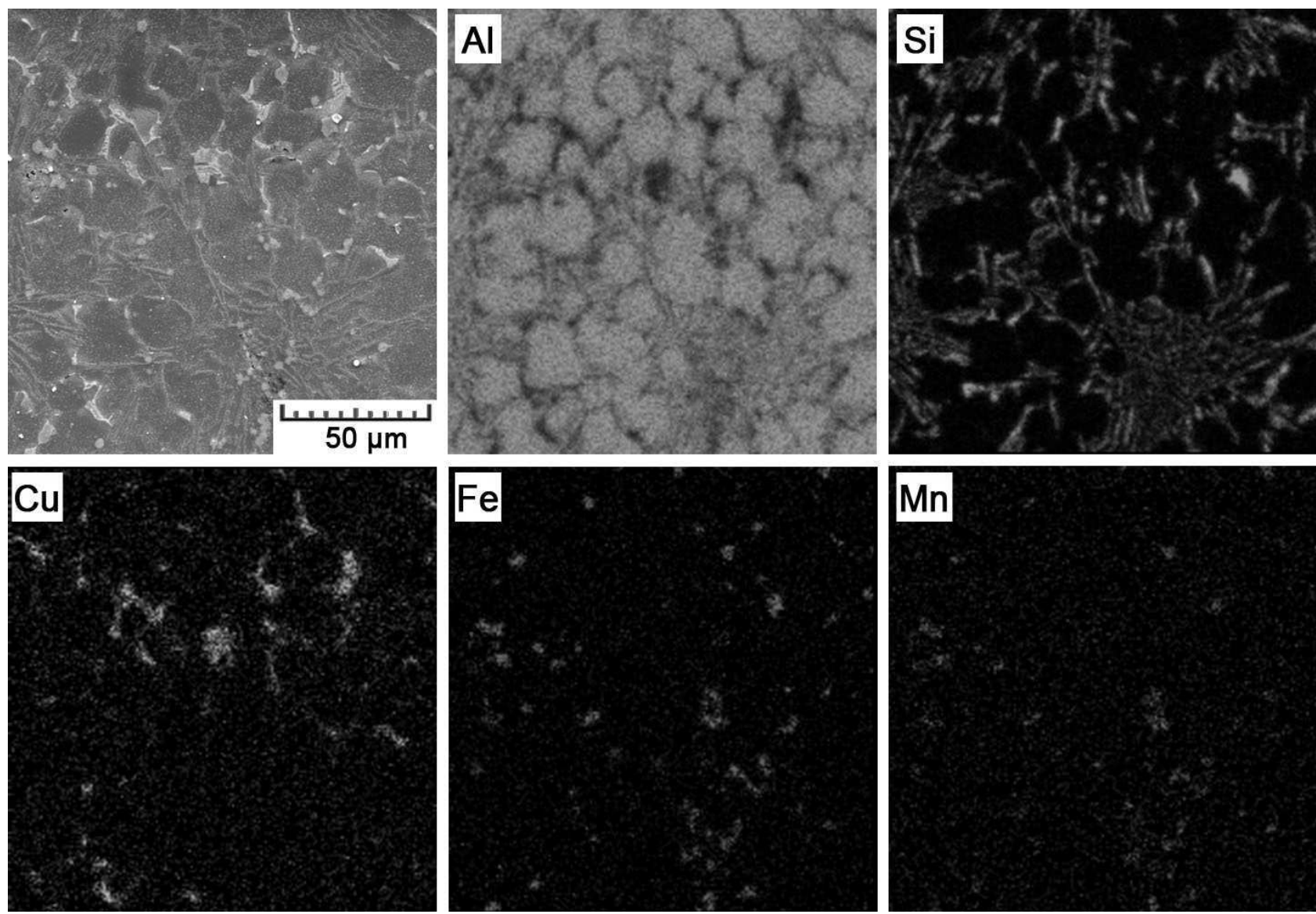

Fig. 3 EDS maps of HPDC AlSi9Cu3Fe alloy. 


\section{Corrosion tests}

The evaluation of corrosion tests brought two type of result: (1) corrosion rate, which indicates the total corrosion resistance of the material; and (2) maximum depth of corrosion attack, which illustrates susceptibility to localized corrosion.

Table 2 summarizes corrosion rates calculated from mass losses determined after the exposition in Audi solution. Compared to the cast alloy, the corrosion rate of the 3 D-printed alloy was increased by $\sim 60 \%$.

Tab. 2 Corrosion rates of casted and 3D-printed AlSigCu3Fe alloy.

\begin{tabular}{|l|l|l|}
\hline & \multicolumn{2}{|c|}{ Corrosion rate } \\
\hline & \multicolumn{1}{|c|}{$\mathbf{g} / \mathbf{m}^{\mathbf{2}} / \mathbf{h}$} & $\mathbf{~ m m} / \mathbf{a}$ \\
\hline HPDC & $33.4 \pm 3.0$ & $106.0 \pm 9.4$ \\
\hline SLM & $52.4 \pm 13.3$ & $166.4 \pm 42.3$ \\
\hline
\end{tabular}
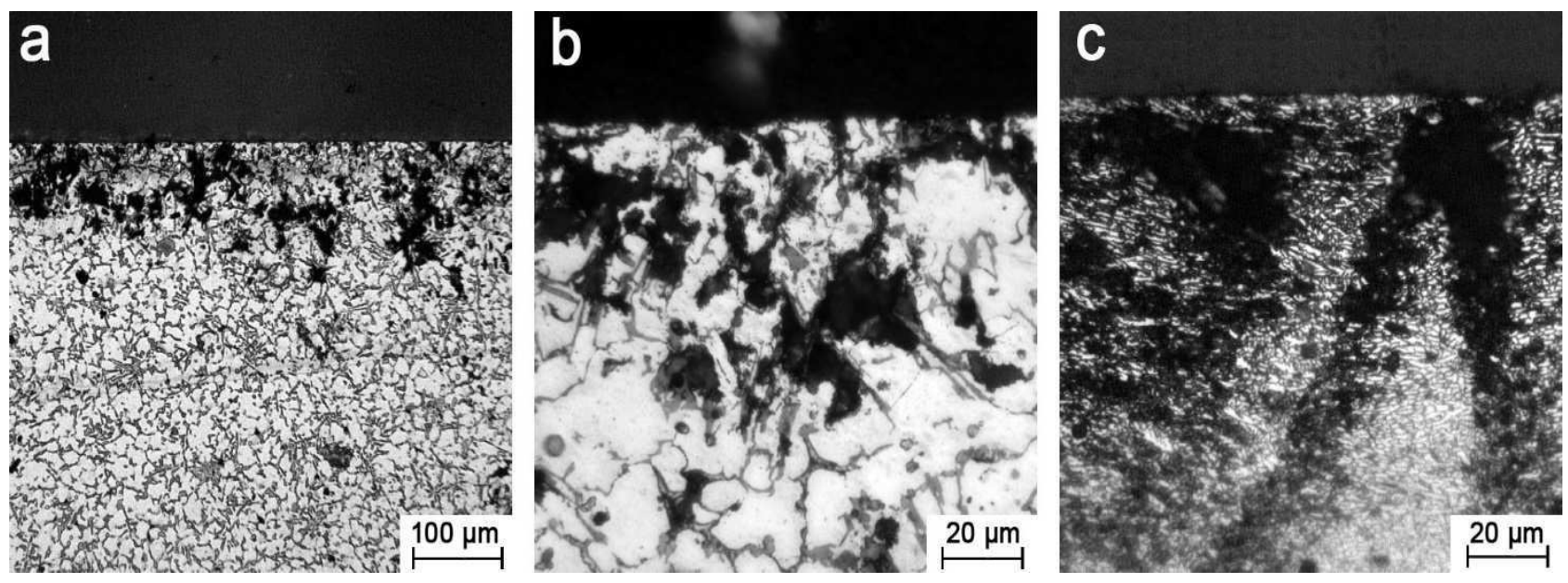

Fig. 4 Localized corrosion AlSi9Cu3Fe alloy: a, b) cast; c) 3D-printed.

In the as-cast state (Fig. 4a,b), the preferential dissolution of eutectic $\alpha$-Al took place while primary dendrites of $\alpha$-Al solid solution were preserved. Figure $4 \mathrm{~b}$ illustrates how the corrosion attack spread along Si needles and cathodic intermetallic phases.

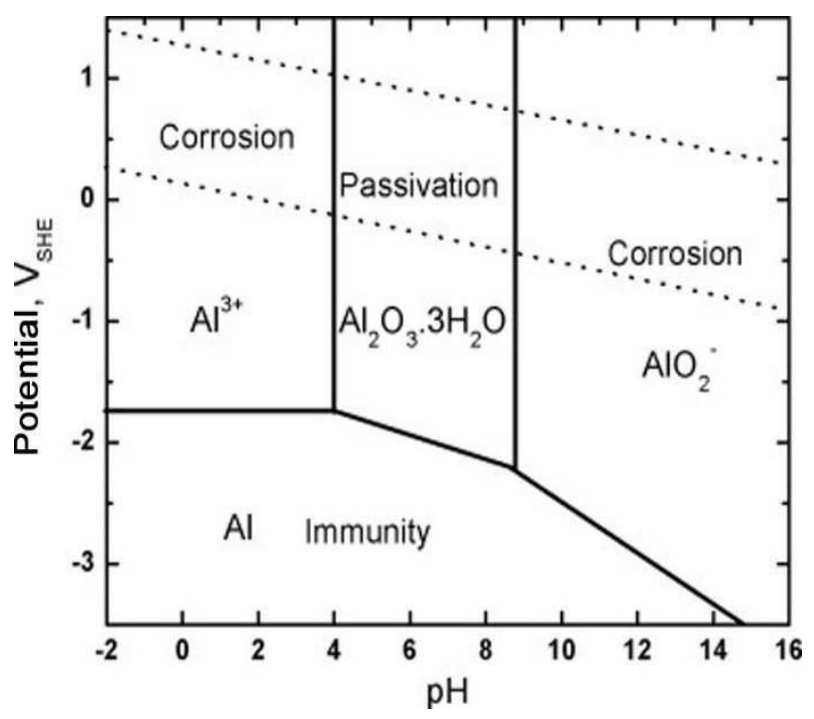

Fig. 5 Pourbaix diagram of aluminium [22].
In both types of samples, localized corrosion attacks were registered (Fig. 4). That is associated with heterogeneous microstructure containing several components. According to Pourbaix diagram (Fig. 5), aluminium is located in the zone of active dissolution at low $\mathrm{pH}$ conditions. In comparison to that, silicon is resistant and remain intact. As the two main components of the AlSi9Cu3Fe microstructure were solid solution of $\alpha-\mathrm{Al}$ and eutectic $\mathrm{Si}$, preferential dissolution of $\alpha$-Al solid solution took place in both material types. Moreover, microgalvanic cells are formed between aluminium matrix and intermetallic phases containing $\mathrm{Cu}, \mathrm{Fe}, \mathrm{Mn}$ or $\mathrm{Zn}$ which are cathodic (present a nobler potential) to aluminium. In the vicinity of such phases, which are cathodically protected, a preferential dissolution of $\mathrm{Al}$ is even enhanced [21].
In the 3D-printed state (Fig. 4c), preferential dissolution of $\alpha$-Al solid solution also occurred. However, as the $\alpha$-Al solid solution is in the form of very fine cells (Fig. $1 b$ ), corrosion propagation was more uniform. Figures $6 \mathrm{~b}$ and $\mathrm{c}$ show micrographs with well visible corrosion-affected bands.

The cells are separated by a network of eutectic $\mathrm{Si}$ which represents a certain barrier against corrosion propagation. Chen et al. [23] have also hinted a barrier effect of Si "shells" during corrosion of AlSi12 in 3.5\% NaCl solution. As soon as this barrier is overcome, an attacked cell dissolves relatively quickly. In the presented micrographs, one can notice enhanced corrosion attack at melt pool borders. At melt pool borders, cells of $\alpha$-Al solid solution are coarser (Fig. 1b) and Si network is slightly disturbed by the tendency of $\mathrm{Si}$ to aggregate into idiomorphic particles [24]. As a consequence, the barrier effect of Si network is weakened and larger corrosion-prone areas are exposed to the aggressive corrosive environment. Similarly, Fathi et al. [25] observed enhanced corrosion at melt pool borders of SLM AlSi10Mg alloy after exposition in $3.5 \% \mathrm{NaCl}$. They attribute it to the higher concentration of separate Si particles along melt pool borders and to the micro-galvanic corrosion between $\mathrm{Si}$ and anodic $\alpha-A l$ matrix. 

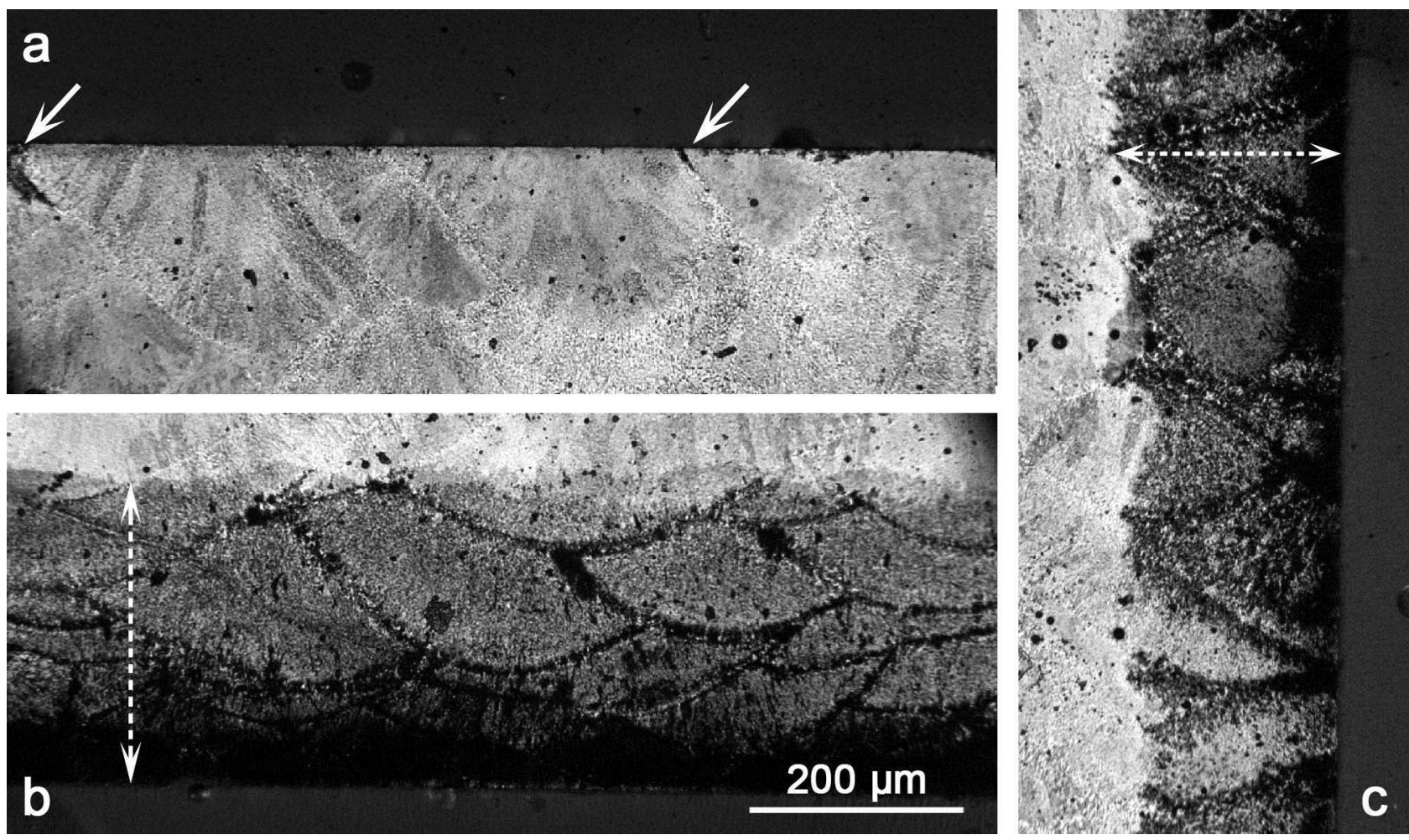

Fig. 6 Corrosion attacks in a 3D-printed sample at its a) top, b) bottom and c) side part. Building direction is from the bottom up. All images are of the same magnification.

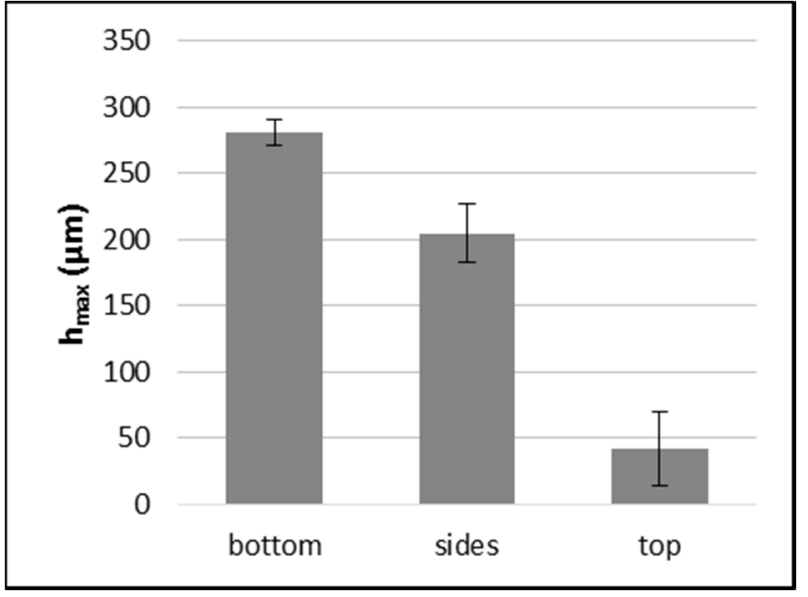

Fig. 7 Maximum depth of corrosion attack penetration in 3D-printed samples.

As the microstructure of 3D-printed AlSi9Cu3Fe alloy is hierarchical and anisotropic, the corrosion attack was not uniform across the sample surface (Fig. 6). The strongest attack occurred at the bottom of the samples (Fig. 6b). The thickness of the corrosion-affected band reached $\sim 280 \mu \mathrm{m}$. That can be explained by the largest proportion of the exposed area occupied by melt pool borders. At melt pool borders, the corrosion attack develops first and easily spreads deeper into the material. Conversely, there was the mildest corrosion at the top of the samples (Fig. 6a). There, mostly melt pool interiors are exposed to the corrosive environment so that the corrosion spreads significantly slower. At sample sides (Fig. $6 \mathrm{c}$ ), more melt pool borders come to the sample surface.
The depth of corrosion-affected zone was medium there. The differences between maximum depths of corrosion attack are graphically summarized in Fig. 7.

In the as-cast samples, the maximum depth of corrosion attack reached $299 \pm 80 \mu \mathrm{m}$. Such a value is comparable to the maximum depth of the corrosion attack observed at the bottom and circumference of the 3D-printed samples. However, such attacks occur only locally, resulting in a lower mass loss and so lower corrosion rate.

\section{Conclusion}

The results of this paper have demonstrated the worsened corrosion resistance of the AlSi9Cu3Fe alloy caused by $3 \mathrm{D}$ printing technology selective laser melting (SLM). SLM yields very fine hierarchical microstructures showing anisotropy due to the process directionality, layer by layer. Compared to the dendritic multiple-phase microstructure yielded by HPDC, cellular microstructure is formed by an oversaturated solid solution of $\alpha$-Al and a network of eutectic Si. Except from small amount of particles of $\mathrm{CuAl}_{2}$ phase randomly occurring in the intercellular Si network, no intermetallic phases are present. In the HPDC microstructure, intermetallic phases cathodic to aluminium represent sites of preferential corrosion attack. Therefore, local corrosion attacks in the eutectic area were observed. In the SLM samples, the corrosion attack was more uniform because fine cells of $\alpha$-Al solid solution were dissolved in the aggressive corrosive environment. The propagation of corrosion attack was enhanced at melt pool borders, where the cells are larger and thereby the proportion of Si network, which exhibits a barrier effect, is lower. 


\section{Acknowledgement \\ Authors wish to thank the Czech Science Foundation (project no. P108/12/G043) and specific university re- search (MSMT No 21-SVV/2018) for the financial sup- port of this research.}

\section{References}

[1] LATTANZI, L., FABRIZI, A., FORTINI, A., MERLIN, M., TIMELLI, G. (2017). Effects of microstructure and casting defects on the fatigue behavior of the high-pressure die-cast AlSi9Cu3(Fe) alloy. In: Procedia Structural Integrity, Vol. 7, pp. 505-512. Elsevier B.V.

[2] VONČINA, M., MOČNIK, N., NAGODE, A., STOIĆ, A., BIZJAK, M. (2017). Dependence of mechanical properties on $\mathrm{Cu}$ content in AlSi9Cu3(Fe) alloy. In: Tehnicki Vjesnik, Vol. 24, pp. 229-231. Technical faculties of the Josip Juraj Strossmayer University of Osijek (UNIOS). Croatia.

[3] PANUŠKOVÁ, M., TILLOVÁ, E., CHALUPOVÁ, M. (2008). Relation between mechanical properties and microstructure of cast aluminum alloy AlSi9Cu3. In: Strength of Materials, Vol. 40, No. 1, pp. 98-101. Springer US.

[4] BOLIBRUChOVÁ, D., MATEJKA, M. (2018). Analysis of microstructure changes for AlSi9Cu3 Alloy caused by remelting. In: Manufacturing Technology, Vol. 18, No. 6, pp. 883-888. Univerzita J. E. Purkyne. Czech Republic.

[5] BIN, S.-B., XING, S.-M., TIAN, L.-M., ZHAO, N., LI, L. (2013). Influence of technical parameters on strength and ductility of AlSi9Cu3 alloys in squeeze casting. In: Transactions of Nonferrous Metals Society of China, Vol. 23, No. 4, pp. 977-982. Elsevier B.V. China.

[6] ZHANG, K.-W., ZHAO, H.-D., OUYANG, X.X., ZHANG, W.-W., LI, Y.-Y. (2009). Microstructures and mechanical properties of Al$\mathrm{Si}-\mathrm{Cu}-\mathrm{T} 4$ solidified at different squeeze pressures. In: The Chinese Journal of Nonferrous Metals, Vol. 4, pp. 006. Elsevier B.V. China.

[7] CHO, J.-I., KIM, C.-W. (2014). The Relationship between Dendrite Arm Spacing and Cooling Rate of Al-Si Casting Alloys in High Pressure Die Casting. In: International Journal of Metalcasting, Vol. 8, No. 1, pp. 49-55. Springer International Publishing.

[8] GRUZLESKI, J. E., CLOSSET, B., Treatment of Liquid Aluminum-Silicon Alloys. 1990, Amer Foundrymens Society, Illinois.

[9] NARAYANAN, L. A., SAMUEL, F. H., GRUZLESKI, J. E. (1995). Dissolution of iron intermetallics in $\mathrm{Al}-\mathrm{Si}$ Alloys through nonequilibrium heat treatment. In: Metallurgical and Materials Transactions A, Vol. 26, No. 8, pp. 2161-2174.

[10] NARAYANAN, L. A., Crystallization and Dissolution studies of Iron Intermetallics in Al-Si Alloys 1994, McGill University: Montreal, Quebec, Canada.

[11] KUCHARIKOVÁ, L., TILLOVÁ, E., BELAN, J., CHALUPOVÁ, M., ŠVECOVÁ, I., ČIČKA, R., UHRÍČIK, M. (2018). Observation on the formation of $\beta$-Al5FeSi phase depending on the content of $\mathrm{Fe}$ in Aluminium Cast Alloy. In: Manufacturing Technology, Vol. 18, No. 4, pp. 611-615. Univerzita J. E. Purkyne. Czech Republic.

[12] HURTALOVÁ, L., TILLOVÁ, E., CHALUPOVÁ, M. (2012). Identification and analysis of intermetallic phases in age-hardened recycled AISi9Cu3 cast alloy. In: Archive of Mechanical Engineering, Vol. 59, No. 4, pp. 385396. Sciendo. Poland.

[13] CECCHEL, S., CORNACCHIA, G., GELFI, M. (2017). Corrosion behavior of primary and secondary AlSi high pressure die casting alloys. In: Materials and Corrosion, Vol. 68, No. 9, pp. 961-969. Wiley V C H Verlag GmbH. Germany.

[14] FOUSOVA, M., DVORSKY, D., VOJTECH, D. (2017). Additively manufactured aluminium AlSi10Mg alloy. In: Manufacturing Technology, Vol. 17, No. 4, pp. 446-451. Univerzita J. E. Purkyne. Czech Republic.

[15] BHAVAR, V., KATTIRE, P., PATIL, V., KHOT, S., GUJAR, K., SINGH, R. A review on powder bed fusion technology of metal additive manufacturing. in 4th International Conference and Exhibition on Additive Manufacturing Technologies-AM-2014, September 2014.

[16] HERZOG, D., SEYDA, V., WYCISK, E., EMMELMANN, C. (2016). Additive manufacturing of metals. In: Acta Materialia, Vol. 117, pp. 371-392. Pergamon - Elsevier Science Ltd. England.

[17] FABRIZI, A., FERRARO, S., TIMELLI, G. (2013). The influence of $\mathrm{Sr}, \mathrm{Mg}$ and $\mathrm{Cu}$ addition on the microstructural properties of a secondary AlSi9Cu3(Fe) die casting alloy. In: Materials Characterization, Vol. 85, pp. 13-25. Elsevier Science Inc. USA.

[18] KHAN, H. M., DIRIKOLU, M. H., KOÇ, E., OTER, Z. C. (2018). Numerical investigation of heat current study across different platforms in SLM processed multi-layer AlSi10Mg. In: Optik, Vol. 170, pp. 82-89. Elsevier GmbH. Germany. 
[19] LI, W., LI, S., LIU, J., ZHANG, A., ZHOU, Y., WEI, Q., YAN, C., SHI, Y. (2016). Effect of heat treatment on AlSi10Mg alloy fabricated by selective laser melting: Microstructure evolution, mechanical properties and fracture mechanism. In: Materials Science and Engineering: A, Vol. 663, pp. 116-125. Elsevier Science SA. Switzerland.

[20] SURYAWANSHI, J., PRASHANTH, K. G., SCUDINO, S., ECKERT, J., PRAKASH, O., RAMAMURTY, U. (2016). Simultaneous enhancements of strength and toughness in an Al12Si alloy synthesized using selective laser melting. In: Acta Materialia, Vol. 115, pp. 285294. Pergamon - Elsevier Science Ltd. England.

[21] KUCHARIKOVÁ, L., LIPTÁKOVÁ, T., TILLOVÁ, E., KAJÁNEK, D., SCHMIDOVÁ, E. (2018). Role of Chemical Composition in Corrosion of Aluminum Alloys. In: Metals, Vol. 8, No. 8, pp. 581. MDPI. Switzerland.

[22] ZHU, J., HIHARA, L. H. (2010). Corrosion of continuous alumina-fibre reinforced $\mathrm{Al}-2 \mathrm{wt} . \%$ $\mathrm{Cu}$-T6 metal-matrix composite in 3.15 wt.\%
$\mathrm{NaCl}$ solution. In: Corrosion Science, Vol. 52, No. 2, pp. 406-415. Pergamon - Elsevier Science Ltd. England.

[23] CHEN, Y., ZHANG, J., GU, X., DAI, N., QIN, P., ZHANG, L.-C. (2018). Distinction of corrosion resistance of selective laser melted Al-12Si alloy on different planes. In: Journal of Alloys and Compounds, Vol. 747, pp. 648-658. Elsevier Science SA. Switzerland.

[24] FOUSOVA, M., DVORSKY, D., VOJTECH, D. (2017). Corrosion properties of AlSi10Mg alloy prepared by gravity casting and 3D printing technology. In: Manufacturing Technology, Vol. 17, No. 6, pp. 847-853. Univerzita J.E. Purkyne. Czech Republic.

FATHI, P., MOHAMMADI, M., DUAN, X., NASIRI, A. M. (2018). A comparative study on corrosion and microstructure of direct metal laser sintered AlSi10Mg_200C and die cast A360.1 aluminum. In: Journal of Materials Processing Technology, Vol. 259, pp. 1-14. Elsevier Science SA. Switzerland. 